\title{
Evaluation of the Ground-Water Flow Model for Northern Utah Valley, Utah, Updated to Conditions through 2002
}

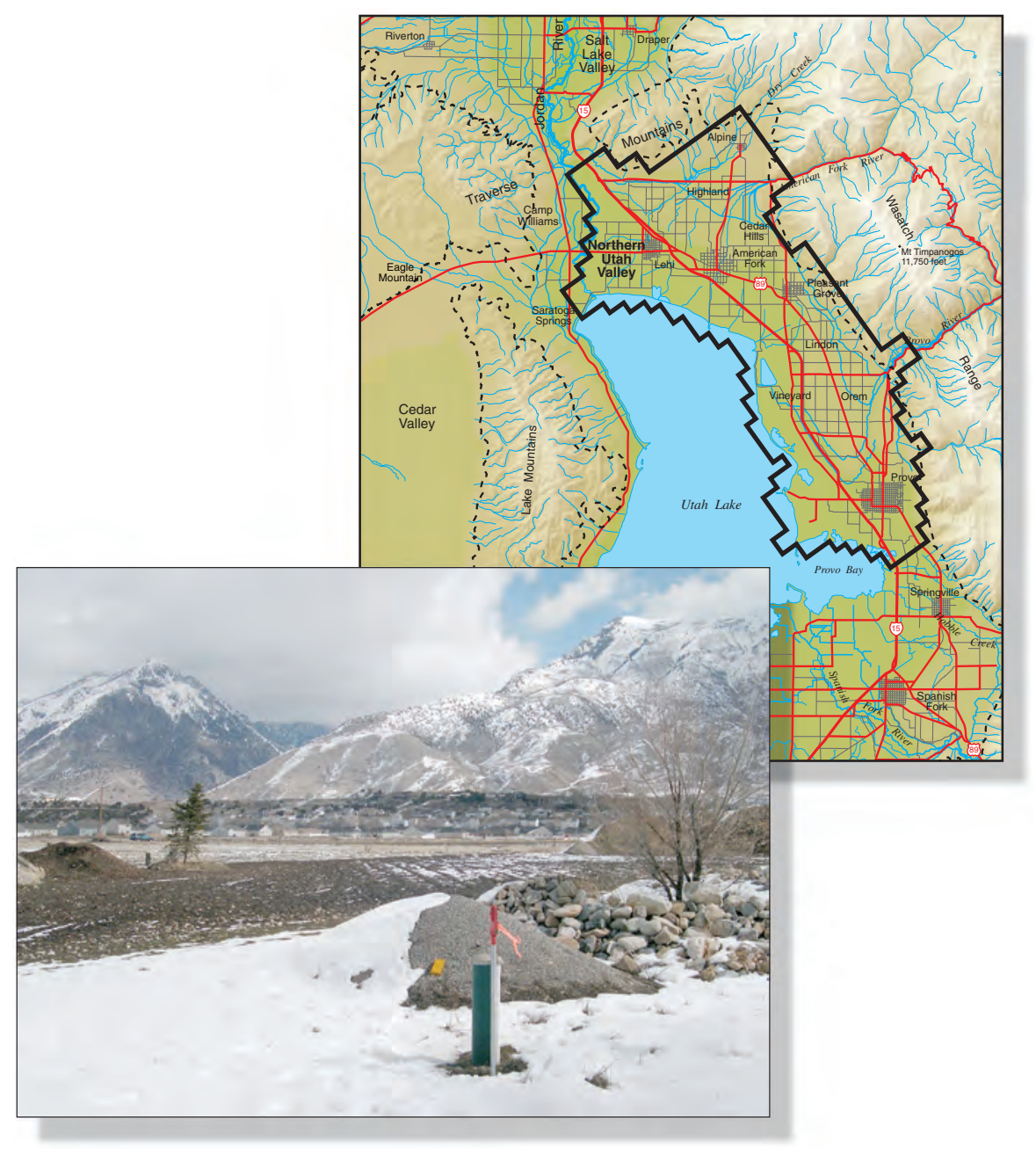

\section{Scientific Investigations Report 2006-5064}

Prepared in cooperation with the Central Utah Water Conservancy District; Jordan Valley Water Conservancy District representing Draper City; Highland Water Company; Utah Department of Natural Resources, Division of Water Rights; and the municipalities of Alpine, American Fork, Cedar Hills, Eagle Mountain, Highland, Lehi, Lindon, Orem, Pleasant Grove, Provo, Saratoga Springs, and Vineyard 
Cover: View looking east toward American Fork Canyon in Utah County, Utah, March 2004. 


\section{Evaluation of the Ground-Water Flow Model for Northern Utah Valley, Utah, Updated to Conditions through 2002}

By Susan A. Thiros

Prepared in cooperation with the Central Utah Water Conservancy District; Jordan Valley Water Conservancy District representing Draper City; Highland Water Company; Utah Department of Natural Resources, Division of Water Rights; and the municipalities of Alpine, American Fork, Cedar Hills, Eagle Mountain, Highland, Lehi, Lindon, Orem, Pleasant Grove, Provo, Saratoga Springs, and Vineyard

Scientific Investigations Report 2006-5064 


\section{U.S. Department of the Interior \\ Gale A. Norton, Secretary}

\section{U.S. Geological Survey \\ P. Patrick Leahy, Acting Director}

\section{U.S. Geological Survey, Salt Lake City, Utah: 2006}

For additional information write to:

U.S. Geological Survey

Director, USGS Utah Water Science Center

2329 W. Orton Circle

Salt Lake City, UT 84119-2047

Email: GS-W-UTpublic-info@usgs.gov

URL: http://ut.water.usgs.gov/

For product and ordering information:

World Wide Web: http://www.usgs.gov/pubprod

Telephone: 1-888-ASK-USGS

For more information on the USGS--the Federal source for science about the Earth, its natural and living resources, natural hazards, and the environment:

World Wide Web: http://www.usgs.gov

Telephone: 1-888-ASK-USGS

Any use of trade, product, or firm names is for descriptive purposes only and does not imply endorsement by the U.S. Government.

Although this report is in the public domain, permission must be secured from the individual copyright owners to reproduce any copyrighted materials contained within this report. 


\section{Contents}

Abstract
Introduction
Purpose and Scope
Ground-Water Hydrology
Description of the Model
Update of the Model to Conditions through 2002
Performance of the Updated Model
Potential Revisions and New Data to Improve the Updated Model
Summary
References Cited

\section{Figures}

Figure 1. Location of northern Utah Valley study area, Utah

Figure 2. Generalized block diagram showing the basin-fill deposits and ground-water system in

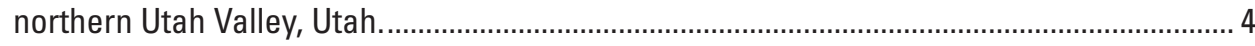

Figure 3. Grid for the model of the ground-water system in northern Utah Valley, Utah ...................... 6

Figure 4. Location of cells simulating recharge and discharge in the model of the ground-water system in northern Utah Valley, Utah.

Figure 5. Specified ground-water discharge from wells in the updated model of the ground-water system in northern Utah Valley, Utah, 1947-2002.

Figure 6. Location of cells simulating flowing and pumping wells in 1981 and 2002 in the updated model of the ground-water system in northern Utah Valley, Utah..

Figure 7. Annual streamflow in the American Fork and Provo Rivers and specified recharge to the ground-water system in the updated model of northern Utah Valley, Utah, 1947-2002

Figure 8. Location of wells with measured and computed water-level changes in the updated model of the ground-water system in northern Utah Valley, Utah.....

Figure 9. Measured water-level change for selected wells during 1981-2003 and computed water-level change for the corresponding model cell and layer in the updated model of the ground-water system in northern Utah Valley, Utah.

Figure 10. Computed water-level decline from the end of 1980 to the end of 2001 in layer 5 of the updated model of the ground-water system and measured water-level decline from March 1981 to March 2002 at 14 wells that correspond to layer 5 in northern Utah Valley, Utah..

Figure 11. Measured water-level altitude for selected wells during 1981-2003 and computed water-level altitude for the corresponding cell and layer in the updated model of the ground-water system in northern Utah Valley, Utah.

Figure 12. Simulated and specified ground-water recharge and discharge in the updated model of the ground-water system in northern Utah Valley, Utah, 1947-2002.. 


\section{Table}

Table 1. Conceptual ground-water budget for the basin-fill aquifer system in northern Utah Valley, Utah

\section{Conversion Factors and Datums}

\begin{tabular}{lcl}
\hline \multicolumn{1}{c}{ Multiply } & By & \multicolumn{1}{c}{ To obtain } \\
\hline & Length & \\
foot (ft) & 0.3048 & meter $(\mathrm{m})$ \\
mile (mi) & 1.609 & kilometer $(\mathrm{km})$ \\
& & \\
\hline \multirow{2}{*}{ square mile $\left(\mathrm{mi}^{2}\right)$} & Area & square kilometer $\left(\mathrm{km}^{2}\right)$ \\
& 2.590 & \\
\hline & & cubic meter $\left(\mathrm{m}^{3}\right)$ \\
acre-foot $($ acre-ft) & Volume & \\
& 1,233 & cubic meter per year $\left(\mathrm{m}^{3} / \mathrm{yr}\right)$ \\
\hline
\end{tabular}

Vertical coordinate information is referenced to the North American Vertical Datum of 1929 (NAVD 29).

Horizontal coordinate information is referenced to the North American Datum of 1983 (NAD 83).

Altitude, as used in this report, refers to distance above the vertical datum. 


\title{
Evaluation of the Ground-Water Flow Model for Northern Utah Valley, Utah, Updated to Conditions through 2002
}

\author{
By Susan A. Thiros
}

\section{Abstract}

This report evaluates the performance of a numerical model of the ground-water system in northern Utah Valley, Utah, that originally simulated ground-water conditions during 1947-1980 and was updated to include conditions estimated for 1981-2002. Estimates of annual recharge to the groundwater system and discharge from wells in the area were added to the original ground-water flow model of the area.

The files used in the original transient-state model of the ground-water flow system in northern Utah Valley were imported into MODFLOW-96, an updated version of MODFLOW. The main model input files modified as part of this effort were the well and recharge files. Discharge from pumping wells in northern Utah Valley was estimated on an annual basis for 1981-2002. Although the amount of average annual withdrawals from wells has not changed much since the previous study, there have been changes in the distribution of well discharge in the area. Discharge estimates for flowing wells during 1981-2002 were assumed to be the same as those used in the last stress period of the original model because of a lack of new data. Variations in annual recharge were assumed to be proportional to changes in total surface-water inflow to northern Utah Valley. Recharge specified in the model during the additional stress periods varied from 255,000 acre-feet in 1986 to 137,000 acre-feet in 1992 .

The ability of the updated transient-state model to match hydrologic conditions determined for 1981-2002 was evaluated by comparing water-level changes measured in wells to those computed by the model. Water-level measurements made in February, March, or April were available for 39 wells in the modeled area during all or part of 1981-2003. In most cases, the magnitude and direction of annual water-level change from 1981 to 2002 simulated by the updated model reasonably matched the measured change. The greater-than-normal precipitation that occurred during 1982-84 resulted in periodof-record high water levels measured in many of the observation wells in March 1984. The model-computed water levels at the end of 1982-84 also are among the highest for the period. Both measured and computed water levels decreased during the period representing ground-water conditions from 1999 to 2002. Precipitation was less than normal during 1999-2002.
The ability of the model to adequately simulate climatic extremes such as the wetter-than-normal conditions of 1982-84 and the drier-than-normal conditions of 1999-2002 indicates that the annual variation of recharge to the groundwater system based on streamflow entering the valley, which in turn is primarily dependent upon precipitation, is appropriate but can be improved. The updated transient-state model of the ground-water system in northern Utah Valley can be improved by making revisions on the basis of currently available data and information.

\section{Introduction}

Ground water is the primary source of drinking water in northern Utah Valley, Utah, and withdrawals for public supply have increased because of rapid population growth. Increased withdrawals coupled with drought conditions during 19992004 caused water levels in many wells in the area to decline to their lowest recorded levels (Burden and others, 2004, p. 40-41). Water-level declines may affect the ability of water managers to withdraw water from public-supply wells or may affect the discharge to springs, drains, streams, Utah Lake, and flowing wells in lower parts of the valley. The effects of withdrawals and modifications to the current hydrologic system are not known, but need to be understood in order to manage and protect the ground-water resource.

The U.S. Geological Survey began a 4-year study of the ground-water system in northern Utah Valley, Utah (fig. 1), in 2003 in cooperation with the Central Utah Water Conservancy District; Jordan Valley Water Conservancy District representing Draper City; Highland Water Company; Utah Department of Natural Resources, Division of Water Rights; and the municipalities of Alpine, American Fork, Cedar Hills, Eagle Mountain, Highland, Lehi, Lindon, Orem, Pleasant Grove, Provo, Saratoga Springs, and Vineyard. The objectives of this study are to develop a better understanding of the groundwater system and to provide information to help determine potential effects of withdrawals on water levels, water quality, and natural ground-water discharge in northern Utah Valley. A new aerially expanded model of the ground-water system in northern Utah Valley is currently (2006) being constructed. 


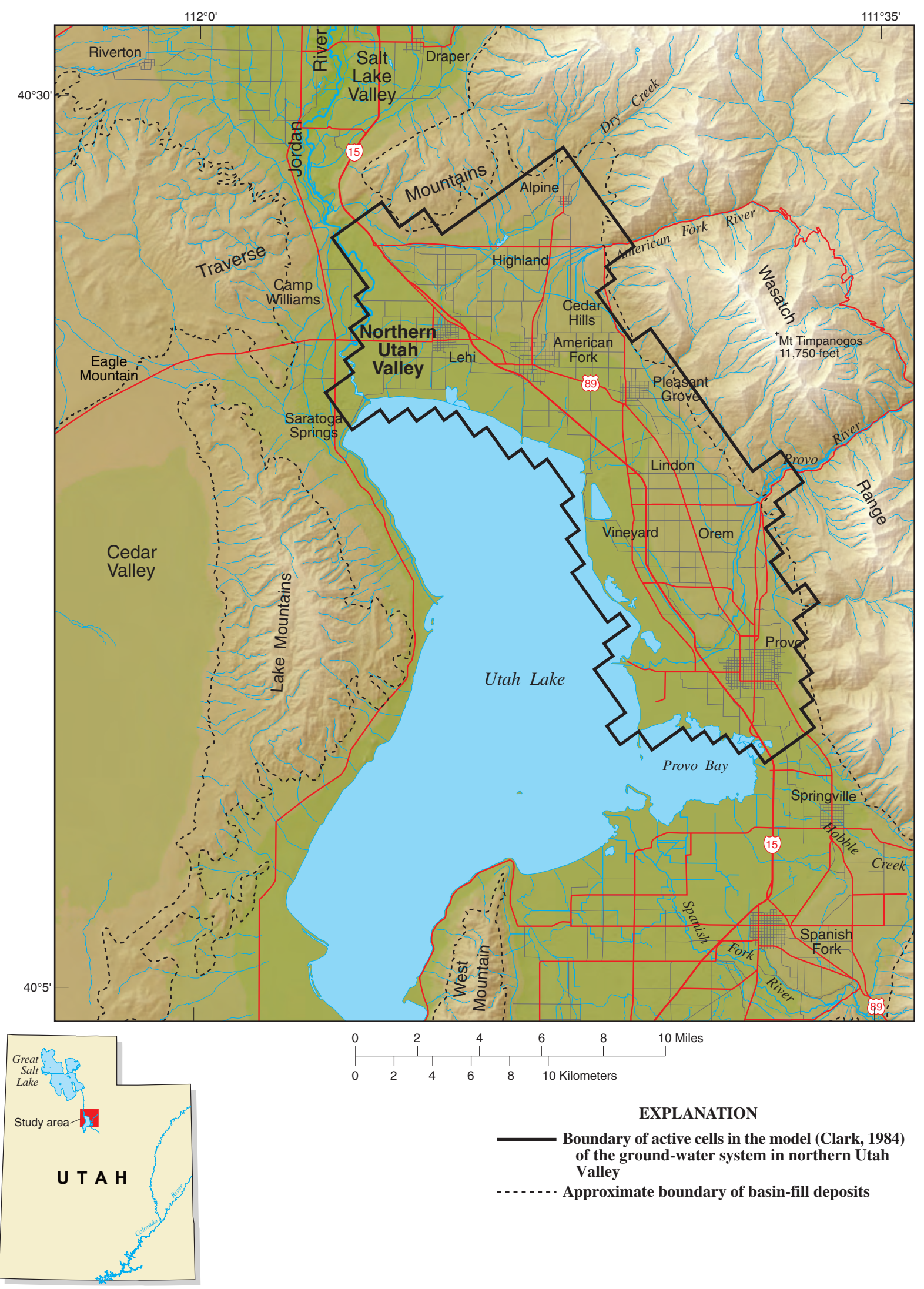

Figure 1. Location of northern Utah Valley study area, Utah. 
The original model (Clark, 1984) was updated and evaluated as part of this study in order to determine how well it simulated ground-water conditions during periods of climatic extremes and to use this information in the construction of the new model. Ground-water flow models can be used by water managers to help understand impacts to the ground-water system from increased development, changing water use, and changes in recharge.

\section{Purpose and Scope}

This report evaluates the performance of a numerical model of the ground-water system in northern Utah Valley, Utah, that originally simulated conditions during 1947-1980 (Clark, 1984) and was updated to include ground-water conditions estimated for 1981-2002. Estimates of annual recharge to the ground-water system and discharge from wells in the area were added to the original ground-water flow model of the area. The ability of the updated transient-state model to match hydrologic conditions determined for 1981-2002 was evaluated by comparing water-level changes measured in wells to those computed by the model. This period includes both a wet and a dry sequence of years that resulted in the highest and lowest water levels measured in most wells with long periods of record in northern Utah Valley. Numerical models of ground-water systems are constructed on the basis of available information and data, and if new data or information become available, testing the performance of a model against those data will result in a better understanding of the model and the ground-water system (Konikow and Bredehoeft, 1992). The performance of the updated model provides information that can be used to guide the study for updating and improving the model and for additional data collection. This assessment also provides valuable information to users of the original model while the new model is being developed.

\section{Description of the Study Area}

The study area covers the northern part of Utah Valley in the north-central part of Utah and corresponds to the extent of basin-fill deposits (fig. 1). It includes the northern part of Utah Lake, a natural, large (about $150 \mathrm{mi}^{2}$ ), shallow (9.5 ft average depth) lake in the lowest part of the valley. Northern Utah Valley is bounded on the north by the Traverse Mountains, on the east by the Wasatch Range, and on the west by the Lake Mountains. The boundary between the northern and southern parts of Utah Valley is arbitrarily located near Provo Bay. Ground water occurring north of this boundary generally discharges in northern Utah Valley and ground water occurring south of this boundary generally discharges in southern Utah Valley. The boundary is poorly defined through Utah Lake because of lack of data.

The land-surface altitude of the basin-fill deposits in the area ranges from 4,489 ft, the level of Utah Lake set by court decree as the maximum legal storage level, above which control gates for diversions are required to be fully opened (compromise level), to about 5,160 ft at the highest level of prehistoric Lake Bonneville deposits along the mountain sides. Mount Timpanogos in the adjacent Wasatch Range reaches an altitude of $11,750 \mathrm{ft}$ and provides runoff to two major streams that enter northern Utah Valley, the American Fork and Provo Rivers.

The population in northern Utah Valley increased from 170,000 in 1980 to 282,000 in 2000, a 66 percent change, and land is rapidly being converted from agricultural to urban uses to accommodate this growth. Prior to these recent changes in land use, the area had water-use patterns associated with agricultural diversions from streams and withdrawals from wells. Changing water-use patterns have the potential to affect ground-water quantity and quality because the location of withdrawals may change and mountain-front streamflow previously used for irrigation will likely be used for municipal supply. Recharge to the ground-water system will likely be reduced because of less seepage from irrigated fields and canals as agricultural areas are converted to residential areas. Mountain-front streams could become piped and diverted upstream from the valley for public supply, also resulting in less recharge to the ground-water system.

\section{Ground-Water Hydrology}

The ground-water system in northern Utah Valley consists of aquifers contained in unconsolidated sediments of Tertiary and Quaternary age that have filled the basin between the surrounding mountains and in consolidated rock in the mountains. The Wasatch Range and the Traverse and Lake Mountains, which are composed primarily of fractured quartzite, limestone, and shale, receive varying amounts of recharge from precipitation. Almost all of the wells in the valley are completed in the basin-fill deposits; therefore, it is considered the principal ground-water aquifer in the study area. Several wells have been recently completed in the consolidated rock along the margins of the valley to provide water for public supply.

Clark and Appel (1985) described the principal groundwater system in northern Utah Valley as consisting of three generally distinct aquifers consisting of predominantly coarser-grained sediment separated by confining layers of clay (fig. 2). The first major aquifer is the shallow artesian aquifer in deposits of Pleistocene age and is typically overlain by blue clay about $50-100 \mathrm{ft}$ below the valley surface that thins and pinches out near the valley margins. Another fine-grained sequence separates the shallow from the deep artesian aquifer of Pleistocene age at about $150 \mathrm{ft}$ below land surface. A few wells penetrate to depths greater than $500 \mathrm{ft}$ below land surface in the valley and are completed in the underlying deposits of Quaternary/Tertiary age. Water levels in wells generally indicate an upward gradient between the confined aquifers. The confining layers become thin or discontinuous near the mountain fronts, resulting in the basin-fill aquifers not being 
differentiated by depth and ground water occurring under unconfined conditions. A shallow unconfined aquifer overlies the uppermost artesian aquifer and can be within a few feet of the land surface in the lower parts of the valley.

Recharge to the basin-fill aquifers is from subsurface inflow from the surrounding consolidated rocks, in addition to losses from streams and canals (table 1 ) in the primary recharge area (fig. 2). Ground-water discharge is primarily to wells, drains, and springs in and around Utah Lake. The difference between the totals for recharge and discharge is mainly the result of insufficient data (Clark and Appel, 1985, p. 85) and changes in the amount of ground water in storage. The value listed for each budget component represents an average annual amount. Data were not available to calculate average values for all components for the same time period.
Table 1. Conceptual ground-water budget for the basin-fill aquifer system in northern Utah Valley, Utah (from Clark and Appel, 1985, table 18)

\begin{tabular}{lr}
\hline \multicolumn{1}{c}{ Budget component } & \multicolumn{1}{c}{\begin{tabular}{c}
\multicolumn{1}{c}{$\begin{array}{c}\text { Acre-feet } \\
\text { per year }\end{array}$} \\
\hline \multicolumn{1}{c}{ Recharge } \\
Seepage from natural channels and irrigation canals
\end{tabular}} \\
$\begin{array}{l}\text { Seepage from irrigated fields, lawns, gardens, and } \\
\text { direct precipitation }\end{array}$ & 73,000 \\
Subsurface inflow from mountains & 15,000 \\
\hline \multicolumn{1}{c}{ Discharge } & 112,000 \\
\hline & 200,000 \\
\hline Wecharge total & 68,000 \\
Drains, springs, and waterways & 135,000 \\
Diffuse seepage to Utah Lake & 7,000 \\
Evapotranspiration & 8,000 \\
Subsurface outflow through Jordan Narrows & 2,000 \\
\hline Discharge total & 220,000 \\
\hline
\end{tabular}

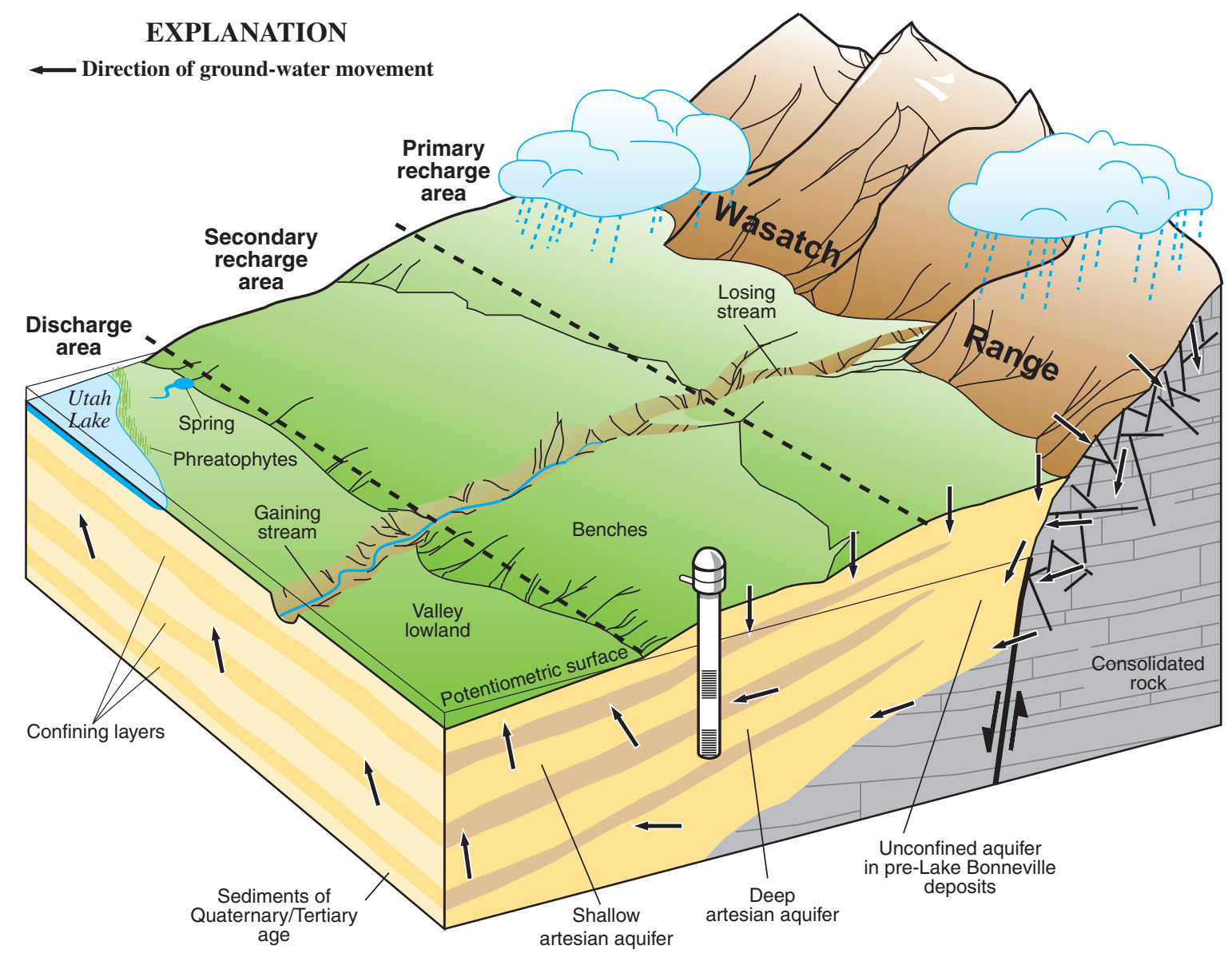

Figure 2. Generalized block diagram showing the basin-fill deposits and ground-water system in northern Utah Valley, Utah. 


\section{Description of the Model}

The U.S. Geological Survey developed a numerical flow model in the early 1980 s to simulate the ground-water system and flow in northern Utah Valley (Clark, 1984). The finite-difference three-dimensional model was constructed using the MODFLOW program (McDonald and Harbaugh, 1988) and consisted of 7 layers, 36 rows, and 19 columns (fig. 3). The largest active cells are $0.85 \mathrm{mi}^{2}$ and generally included areas where data were sparse. The smallest cells are $0.25 \mathrm{mi}^{2}$ and generally included areas with wells, ground-water withdrawals, or historic water-level measurements.

Impermeable boundaries were used to simulate the contact between the valley and mountains in the model area. The impermeable boundaries are represented in the model as inactive cells (fig. 3). The approximate location of the contact between the basin-fill deposits and consolidated rock is along the eastern Traverse Mountains and the western flank of the Wasatch Range. Inactive cells also were placed about one cell lakeward from the eastern shoreline of Utah Lake and beneath layer 7 , on the assumption that there is no upward flow from below.

Simulated recharge to the ground-water system included seepage from streams, irrigation canals, irrigated fields, lawns, and gardens; infiltration of precipitation; and subsurface inflow from consolidated rocks in the primary recharge area (fig. 2), a narrow strip of land adjacent to the mountain fronts (Clark and Appel, 1985, fig. 9) that is not underlain by thick layers of fine-grained material that impede the downward movement of water. Recharge was distributed to the cells near the eastern extent of the valley according to an initial rate determined for steady-state conditions (fig. 4) and was specified by Clark (1984) as rates input to the Recharge Package (McDonald and Harbaugh, 1988, p. 7-1). Groundwater recharge from subsurface inflow along the mountain front calculated by the model using constant-head cells under steady-state conditions was about 100,000 acre-ft/yr. The constant-head cells were replaced with specified recharge rates at the end of the steady-state calibration. The total amount of recharge to the ground-water system simulated under steadystate conditions was 190,000 acre-ft/yr.

Constant-head cells were used along the Jordan River and the eastern shoreline of Utah Lake to simulate ground-water discharge by upward leakage from the artesian aquifers (fig. 4). They are placed in layers 1, 2, and 3 at approximately the river or the compromise lake-surface altitude. Ground-water discharge from springs, seeps, and drains was simulated with the Drain Package (McDonald and Harbaugh, 1988, p. 9-1). The Drain Package allows water to discharge from the aquifer at a rate proportional to the difference between the head in the aquifer and some fixed altitude when the head in the aquifer is above that altitude. Discharge stops if the head falls below the specified altitude for that cell.

Some water moving from model layers 3,5 , and 7 , representing the artesian aquifers, to layer 1 , which represents the upper unconfined aquifer, was simulated as eventually dis- charging at the land surface by evapotranspiration (fig. 4) with the Evapotranspiration Package (McDonald and Harbaugh, 1988, p. 10-1). Discharge by evapotranspiration is dependent on depth to water and is, therefore, a head-dependent process.

The model begins with steady-state conditions that were assumed to exist in 1947, before the construction of largeyielding pumped wells. Model-computed water levels were compared to measured water levels for 1947 and included 63 water levels in layer 3, 48 in layer 5, and 9 in layer 7 (Clark, 1984, p. 22). Most of the model-computed water levels are within $5 \mathrm{ft}$ of those measured in wells; however, in areas with few data, the difference may be as much as $10 \mathrm{ft}$.

The transient-state calibration of the model consisted primarily of varying aquifer properties along with recharge estimates and discharge data from wells for 1947-80 and comparing the model-computed water levels with water levels measured during the late winter-early spring of 1948-81. The transient period was divided into seven stress periods representing intervals of time when total discharge from wells was fairly constant. The periods with similar pumping rates are 1947-50, 1951-55, 1956-62, 1963-65, 1966-73, 1974-77, and 1978-80. Simulating fluctuations in well discharge during model calibration from one multiyear stress period to the next did not result in a reasonable match between water-level changes computed in the model and water-level changes measured during the calibration period (Clark, 1984). Therefore, recharge also was varied to provide a better match between model-computed and measured water-level changes.

Variations in annual recharge were assumed to be proportional to changes in total surface-water inflow to northern Utah Valley. The initial rate of recharge obtained from the steadystate calibration was multiplied by one-half of the percentage change from the average surface-water inflow during a given time period (Clark, 1984, p. 27) and applied to all of the model cells that simulate recharge.

$$
\text { Multiplier }=\left[\left(S W-S W_{\text {ave }}\right) / S W_{\text {ave }}\right] \times 0.5
$$

where: $S W$ is the estimated annual surface-water inflow to the model area, in acre-ft and

$S W_{\text {ave }}$ is the estimated average surface-water inflow to the model area, in acre-ft.

For example, if surface-water inflow for a given time period was 20 percent above average, then recharge for that time period was assumed to be 10 percent above the initial rate. Recharge to the ground-water system may change substantially from one year to the next, and such changes are a major cause for variations of water levels in northern Utah Valley.

Clark (1984, fig. 16) compared measured and modelcomputed water-level changes for 16 observation wells with data for some of or all the pumping periods. The computed water levels were close to the measured levels at most of the wells. At wells where the computed levels did not match the measured levels, the magnitude of the water-level changes from one pumping period to the next were generally about the same. 


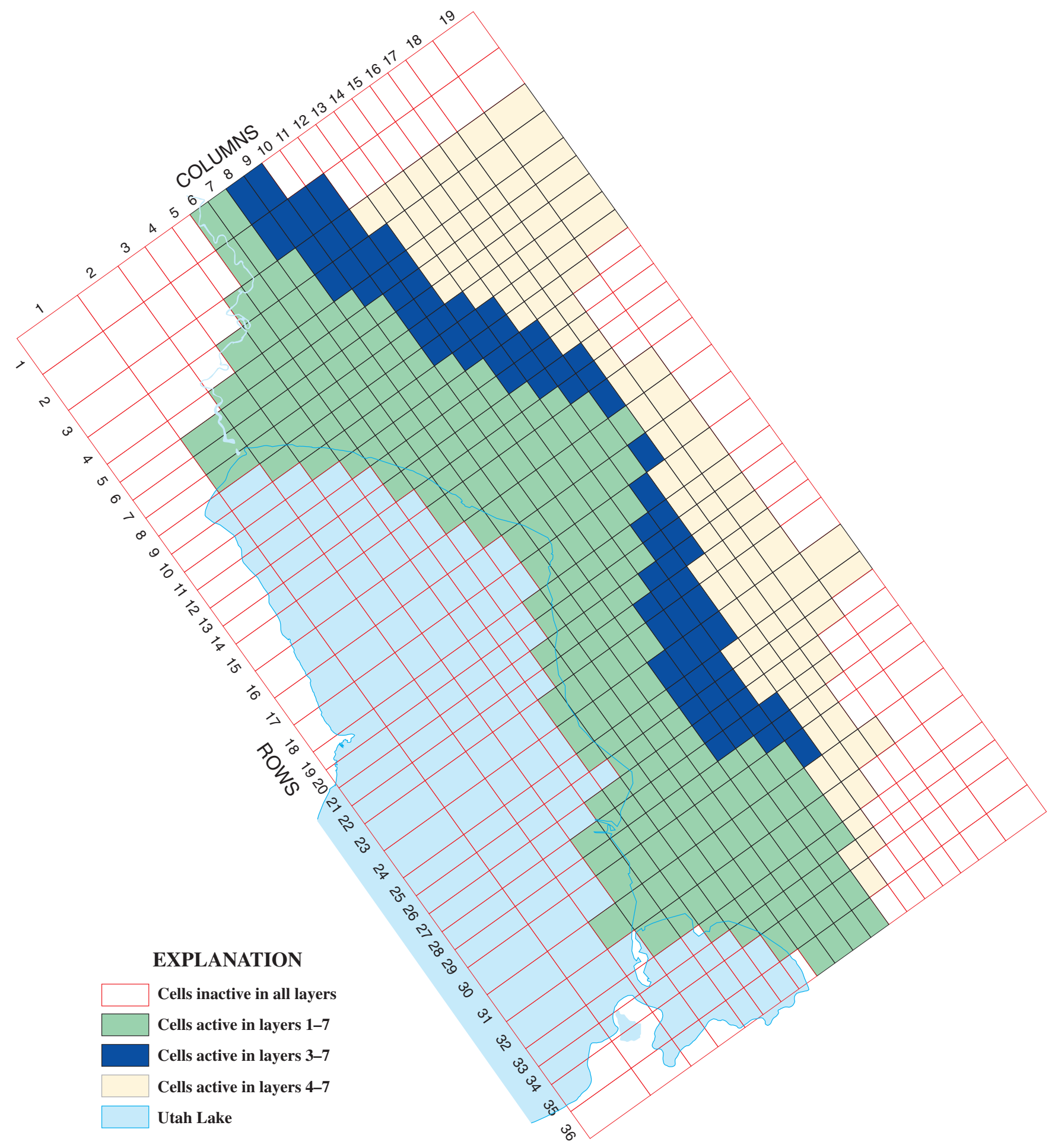

Figure 3. Grid for the model of the ground-water system in northern Utah Valley, Utah. 




Figure 4. Location of cells simulating recharge and discharge in the model of the ground-water system in northern Utah Valley, Utah. 


\section{Update of the Model to Conditions through 2002}

The files used in the transient-state model (Clark, 1984) were imported into MODFLOW-96 (Harbaugh and McDonald, 1996) for use in updating the model to conditions through 2002. MODFLOW-96 is an updated version of MODFLOW (McDonald and Harbaugh, 1988). The main model input files modified as part of this effort were the well and recharge files. Other parts of the updated model described in the remainder of this report are the same as in the original model (1947-80), except for factors related to the extended simulation period. The number of stress periods listed in the Basic Package file was changed from 7, representing the period from 1947-80 in the original model, to 29, which includes an additional 22 annual stress periods representing the period from 1981-2002. Other input files were adjusted to account for the additional stress periods. Hydraulic properties of the aquifers and confining layers, the distribution of recharge, the use of headdependent cells to simulate ground-water discharge to springs, drains, and evapotranspiration, and the use of constant-head cells to simulate discharge to Utah Lake, the Jordan River, and subsurface outflow through the Jordan Narrows were not changed in the updated model.

Discharge from pumping wells in northern Utah Valley was estimated on an annual basis for 1981-2002. Annual withdrawals from irrigation wells were estimated from unpublished data in the files of the U.S. Geological Survey Utah Water Science Center office in Salt Lake City, Utah. Public-supply and industrial well withdrawal data were obtained from the Utah Division of Water Rights (written commun., 2003). Withdrawals from wells in the area were estimated to be about 72,500 acre-ft/yr in 2002 and averaged about 72,800 acre-ft/yr during 1999-2002. Although the amount of average annual withdrawals from wells has not changed much from what was reported in the previous study (table 1), there have been changes in the distribution of well discharge in the area. Since 1981, more than 40 large-yield wells have been constructed to supply the growing residential areas while many flowing wells used for irrigation, stock, and domestic use have been destroyed or are no longer in use.

Records of well discharge prior to 1963 are less complete than for the later periods and flowing-well discharge is assumed to be a major part of the discharge from wells before 1963 (Clark, 1984, p. 29). Discharge estimates for flowing wells during 1981-2002 were assumed to be the same as those used in the last stress period of the original model because of a lack of new data. Because discharge from flowing wells for irrigation likely has decreased since 1980 as a result of of the change from agricultural to residential land use in the area, this assumption results in a higher-than-actual discharge estimate for flowing wells during 1981-2002. Additional study of land-use changes would likely provide an improved estimate. Estimated ground-water withdrawals from wells used in the updated model for each stress period from 1947 to 2002 are shown in figure 5 . The location of model cells containing the wells simulated in 1981 and 2002 is shown in figure 6.

Discharge to wells is represented as a specified-flux boundary using the Well Package (McDonald and Harbaugh, 1988, p. 8-1). Required input data for the Well Package are the model cell (row and column) and layer that correspond to the location and depth of the open intervals (perforated, screened, or open hole) of the well. The distribution of discharge from a pumped well open to more than one model layer representing an artesian aquifer was the same as that used in the original model. Discharge from wells drilled after 1980 that were open to more than one model layer simulating artesian aquifers was divided evenly between the layers on the basis of similar distribution of transmissivity across the layers (Clark, 1984, p. 15-17).

Recharge estimates for 1981-2002 were included in the updated model on the basis of annual change from average surface-water inflow to the area according to the method described by Clark (1984, p. 27). Annual streamflow totals determined for the American Fork River (U.S. Geological Survey gaging station 10164500) and the Provo River below Deer Creek Dam (U.S. Geological Survey gaging station 10159500) were added to estimates of flow from the other streams entering the valley. Streamflow estimates for the ungaged streams were calculated by correlating flow with that of gaged streams along the Wasatch Range in Salt Lake Valley to the north. The amount of streamflow determined by this method does not distinguish between water that was diverted to or from the drainage basin and water that originated in or drained to the basin. Recharge specified in the model during the additional stress periods varied from 255,000 acre-ft in 1986 to 137,000 acre-ft in 1992 (fig. 7).

\section{Performance of the Updated Model}

The ability of the updated transient-state model to match hydrologic conditions determined for 1981-2002 was evaluated by comparing water-level changes measured in wells to those computed by the model. Model performance was not evaluated for fluctuations in natural ground-water discharge because few observations of changes in flow were available for 1981-2002. Water-level measurements made in February, March, or April were available for 39 wells in the modeled area during all or part of 1981-2003 (fig. 8). Most of the water-level measurements were made during the month of March, a time of the year when there is less stress on the ground-water system from pumping, evapotranspiration, snowmelt runoff, or irrigation. This water-level measurement was used to represent the cumulative effects from the preceding year on ground-water conditions at each well.

The performance of the updated model can be assessed by comparing how closely it simulated the water-level change since 1981. The measured water-level change at a well was determined by subtracting the water level measured in 


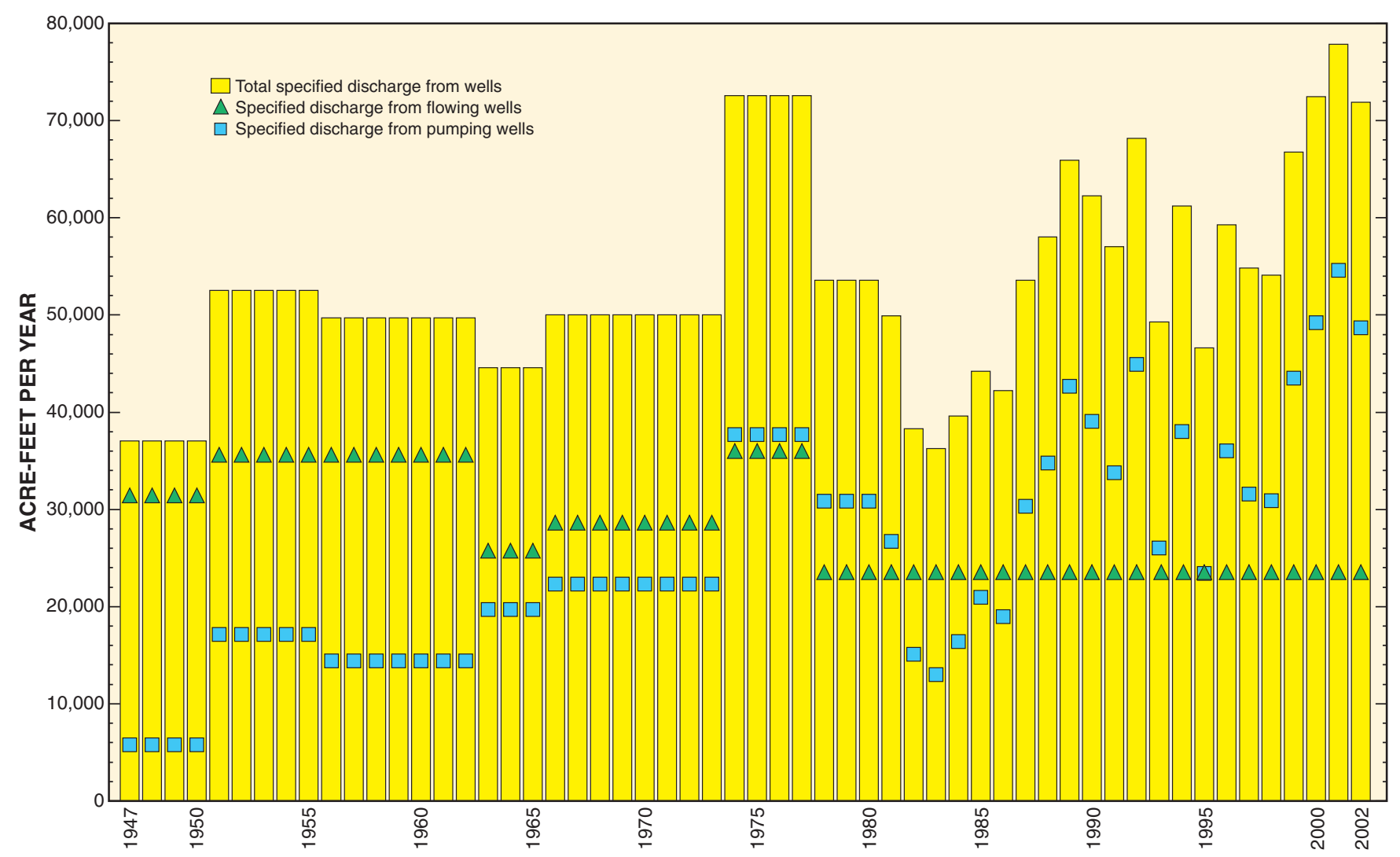

Figure 5. Specified ground-water discharge from wells in the updated model of the ground-water system in northern Utah Valley, Utah, 1947-2002.

March 1981, or the first available March measurement after 1981, from water levels measured in the well during February, March, or April (preferably March) 1981-2003. These measured water-level changes were compared to water-level changes computed at the end of the preceding calendar year by the model for the cell and layer that correspond to the well (fig. 8). The model-computed water-level change was determined by subtracting the water level computed at the end of 1980, which corresponds to the water-level measurement made in March 1981 (or the computed water level that corresponded to the first available March measurement after 1981), from water levels computed by the model at the end of 1980-2002. For example, the measured water-level change from March 1981 to March 2003 was compared to the model-computed change from the end of 1980 to the end of 2002. This method focuses on water-level change, so that estimated water levels used in the calibration of the original model in areas with few or no data do not overwhelm the comparison.

In most cases, the magnitude and direction of annual water-level change from 1981 to 2002 computed by the updated model reasonably matched the measured change (fig. 9). The similar response of annual model-computed water-level change and measured water-level change with time indicates that the variation in the amount of recharge specified annually is generally a good approximation of the actual variation in recharge. Recharge estimates determined from total annual surface-water inflow to the valley resulted in large increases in model-computed water levels during the wet years of 1982-84. The greater-than-normal precipitation that occurred during 1982-84 resulted in period-of-record high water levels measured in many of the observation wells in March 1984. The model-computed water levels at the end of 1982-84 also are among the highest for the period and are only exceeded by the water levels computed at the end of 1986, the year with the most recharge simulated.

The water level measured in March 1987 is lower than the water level measured in March 1984 in all but one of the wells with measurements (well 27). The high model-computed water levels at the end of 1986 indicate some error in the amount of recharge simulated in 1986. The total streamflow measured in the American Fork River in 1986 is similar (within 8 percent) to the average of what was measured during 1982-84 (fig. 7). The American Fork River drains the Wasatch Range adjacent to the northern part of Utah Valley. The total streamflow measured in the Provo River below Deer Creek Dam was 36 percent more in 1986 than the average total streamflow during 1982-84 (fig. 7). Streamflow at the Provo River below Deer Creek Dam is regulated and includes water diverted from outside of the Wasatch Range drainage basin. Recharge to the ground-water system specified to the model is influenced by factors that are not considered in the simulated correlation between annual recharge and total surface-water inflow (eq. 1). 


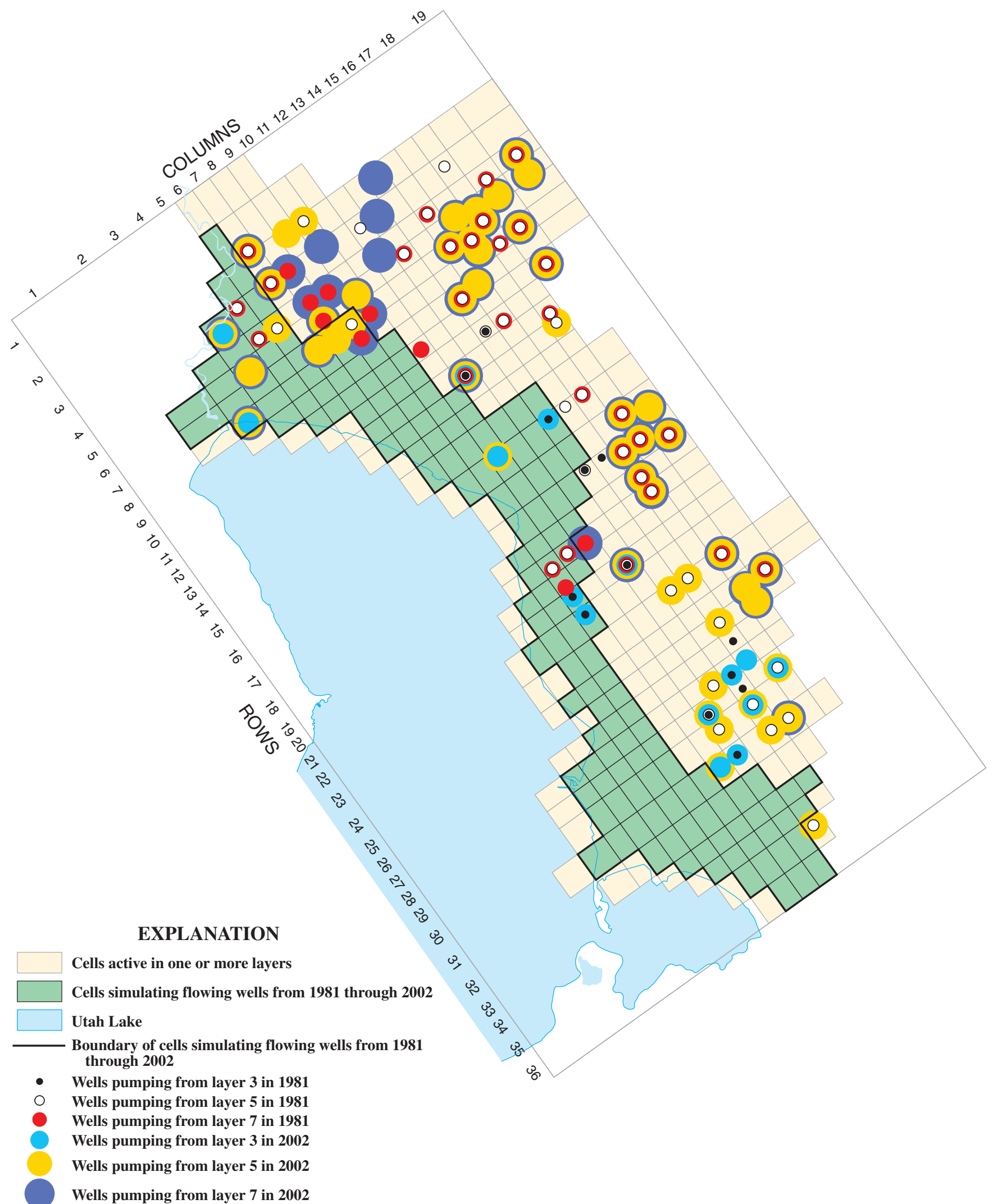

Figure 6. Location of cells simulating flowing and pumping wells in 1981 and 2002 in the updated model of the ground-water system in northern Utah Valley, Utah. 


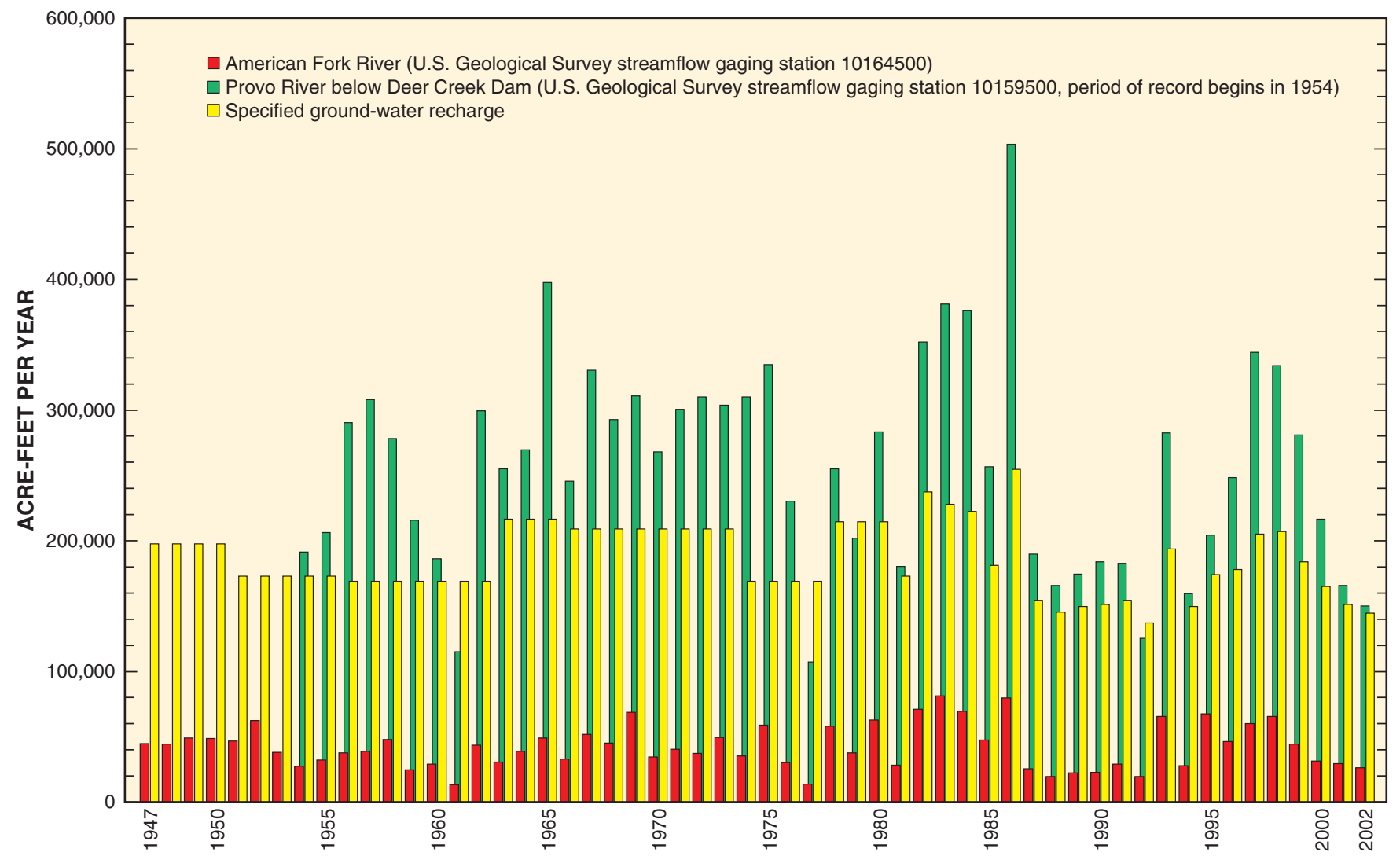

Figure 7. Annual streamflow in the American Fork and Provo Rivers and specified recharge to the ground-water system in the updated model of northern Utah Valley, Utah, 1947-2002.

Both measured and model-computed water levels decreased during the period representing ground-water conditions from 1999 to 2002. The water levels measured in March 2003 were the lowest measured at that time of the year for the period of record for many of the wells. Precipitation measured at Silver Lake near Brighton, Utah, about 10 mi northeast of the study area and at an altitude of about 8,740 ft in the Wasatch Range, was less than normal during 1999-2002. This drought is comparable in length and magnitude to previous droughts since 1965; however, with population growth and increased demand for water in the area, the general effect is more severe. The water-level declines at the end of 2002 were about the largest computed and were similar to those at the end 1992 (fig. 9), the year with the least amount of applied recharge in the updated model.

Water-levels declines computed at the end of 2001 and compared to water-level declines measured at 37 wells in March 2002 ranged from $11.3 \mathrm{ft}$ less than declines measured at well 14 to $5.5 \mathrm{ft}$ greater than declines measured at well 33 (fig. 9). Model-computed water-level changes at the end of 2001 were within $5 \mathrm{ft}$ of measured water-level changes at 70 percent of the wells with water-level measurements from March 2002. Measured water-level declines in many of the wells in the northwestern part of the modeled area near Utah Lake are larger than those computed by the model for a corresponding cell (fig. 10). Model-computed water-level declines are not as large as measured water-level declines from March 2000 to March 2002, a period with drier-than-normal conditions, in wells $2,13,14,15$, and 16 (fig. 9). This is a discharge area where wells have historically flowed, but pumping has increased substantially from when the original model was calibrated. Also, more recharge from the constant-head cells occurs during periods with less overall recharge because the simulated water level drops below that of the constant-head boundary. Model parameters used to simulate aquifer properties, such as storage coefficient and transmissivity, discharge and recharge from constant-head cells, and the specified discharge from flowing wells may need adjustment in this area.

Measured water-level changes in the eastern part of the modeled area, in or near where recharge was specified and ground water is unconfined, generally did not match computed water-level changes as well as in other areas. Differences between measured and computed water-level change exceeded $20 \mathrm{ft}$ in wells 3, 4, and 29 at times in the 1990s (fig. 9). These wells are near American Fork Canyon and the measured water-level changes are likely affected by the timing of runoff and ground-water recharge occurring at and near the mountain front. Model-computed water-level changes in the area are affected more by the large influence of annual streamflow in the Provo River on the recharge multiplier and less on the actual variation in annual streamflow in the American Fork River (fig. 7). 


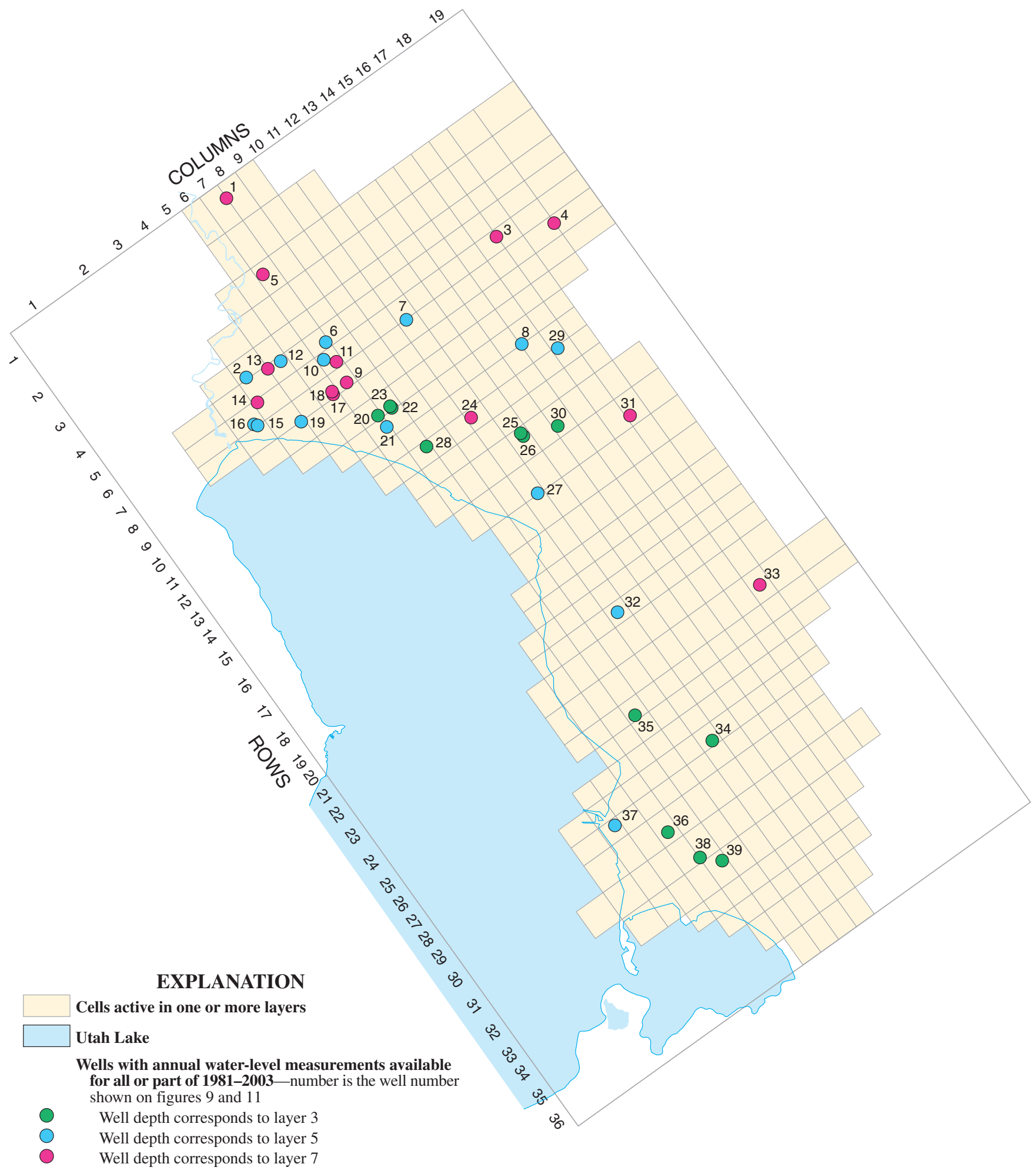

Figure 8. Location of wells with measured and computed water-level changes in the updated model of the ground-water system in northern Utah Valley, Utah. 

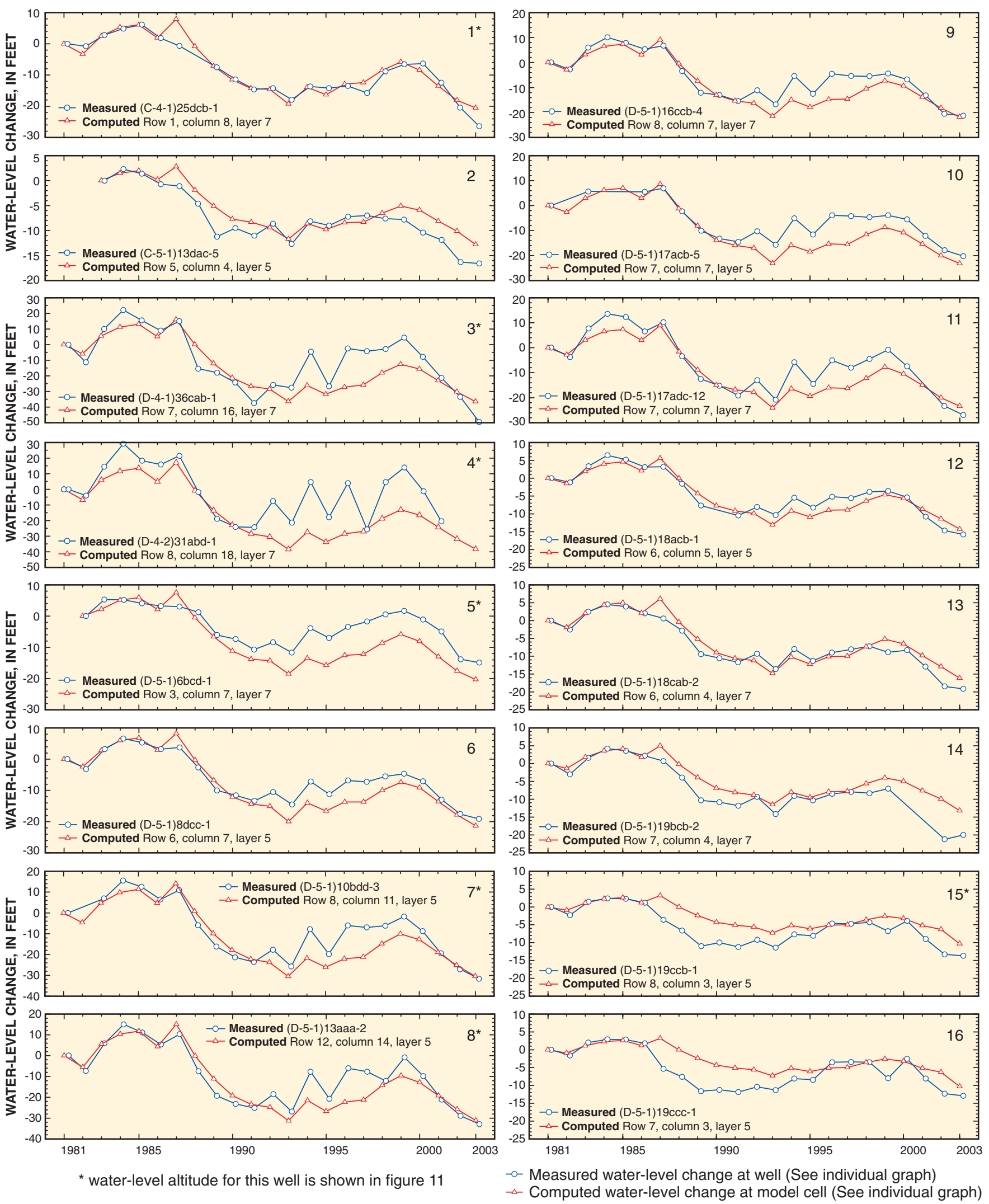

Figure 9. Measured water-level change for selected wells during 1981-2003 and computed water-level change for the corresponding model cell and layer in the updated model of the ground-water system in northern Utah Valley, Utah. 

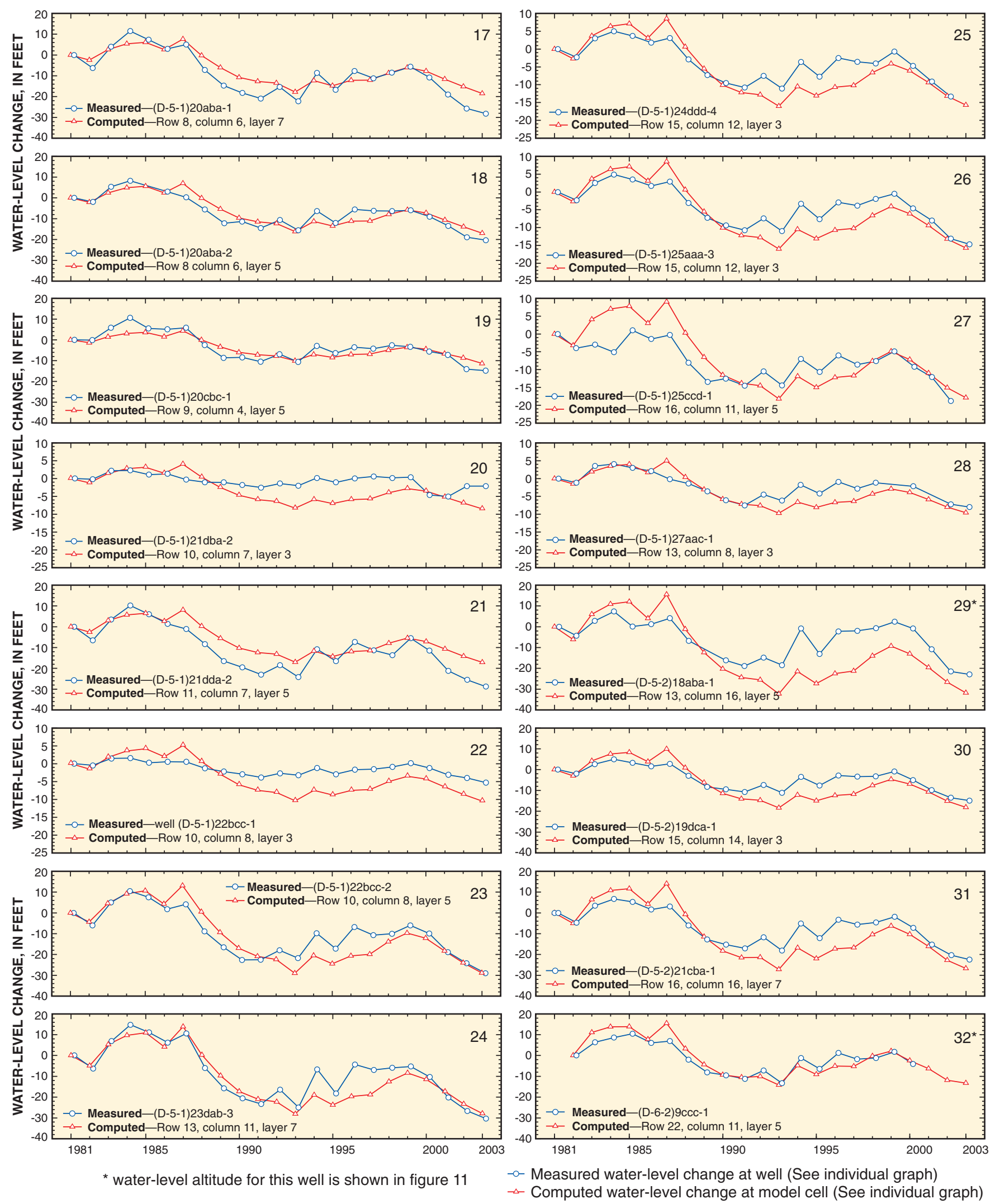

Figure 9. Measured water-level change for selected wells during 1981-2003 and computed water-level change for the corresponding model cell and layer in the updated model of the ground-water system in northern Utah Valley, Utah—Continued. 

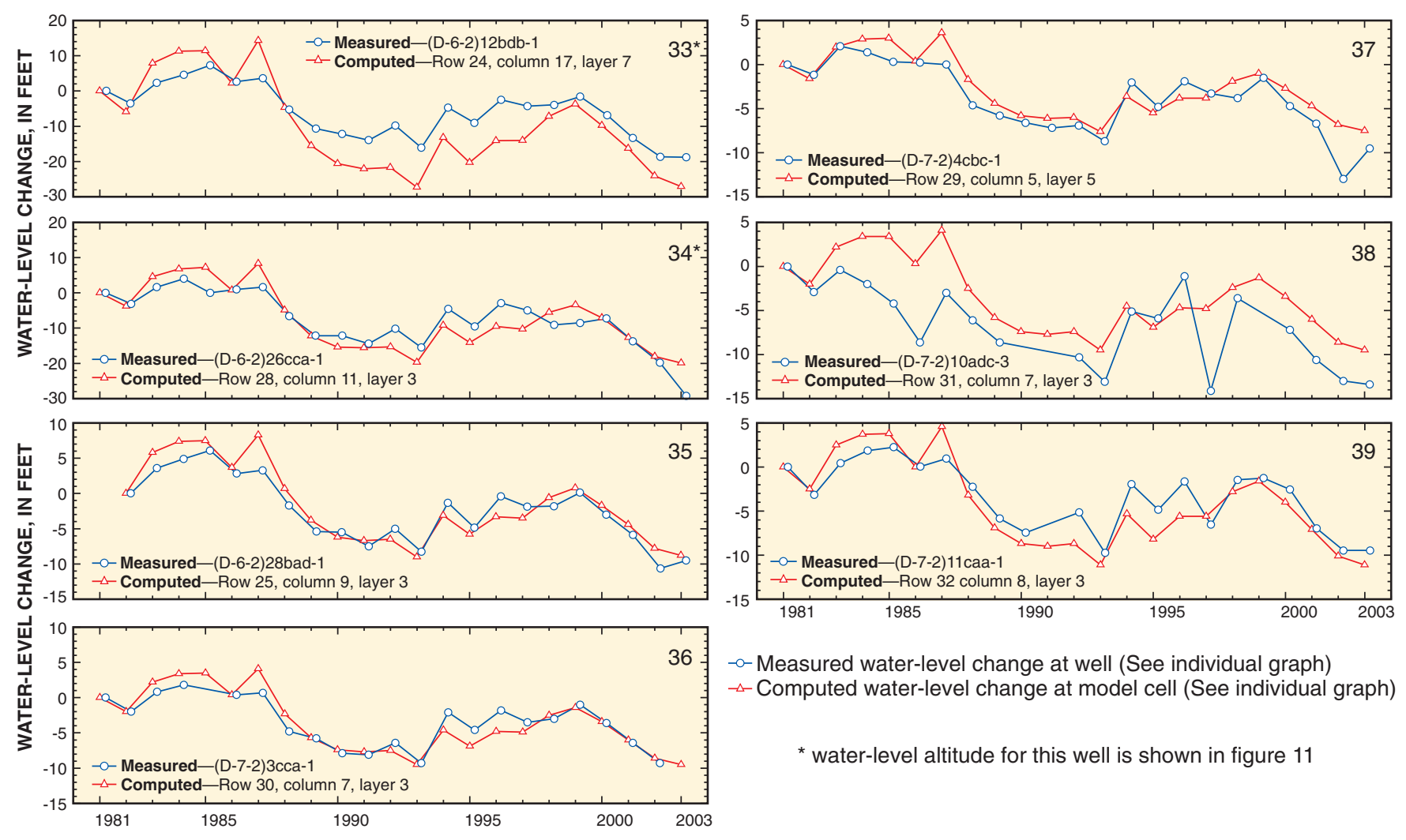

-o-Measured water-level change at well (See individual graph)

$\triangle-$ Computed water-level change at model cell (See individual graph)

* water-level altitude for this well is shown in figure 11

Figure 9. Measured water-level change for selected wells during 1981-2003 and computed water-level change for the corresponding model cell and layer in the updated model of the ground-water system in northern Utah Valley, Utah—Continued.

Eleven wells with water levels measured during 1981-2003 did not have water-level measurements made in March prior to 1981 (fig. 11) and, therefore, were not used to calibrate the original model. The updated model computed a higher water-level altitude for the cell and layer that corresponded to wells 1, 5, 29, and 33 than was measured, with offsets generally more than $20 \mathrm{ft}$ (fig. 11). These wells are located near model boundaries and indicate that the model needs some refinement in these areas. Water levels measured at wells 3, 4, $7,8,15,32$, and 34 generally were similar to those computed by the updated model for the period representing ground-water conditions during 1981-2002, indicating that the starting heads used in the original model were a close approximation.

The ability of the model to adequately simulate climatic extremes such as the wetter-than-normal conditions of 1982-84 and the drier-than-normal conditions of 1999-2002 indicates that the annual variation of recharge to the groundwater system based on streamflow entering the valley, which in turn is primarily dependent upon precipitation, is appropriate but can be improved. The model's response to years with less specified recharge and increased withdrawals from wells is a decrease in discharge from drains simulating springs, constant-head cells simulating seepage to the Jordan River and Utah Lake, and evapotranspiration (fig. 12). Years with more recharge generally correspond to more discharge from drains and constant-head cells and decreased withdrawals from wells. The difference between total recharge and total discharge for a year is water added to or removed from storage. Predictive simulations of interest would include a period with less recharge coupled with increased withdrawals from wells greater than the amounts to date.

\section{Potential Revisions and New Data to Improve the Updated Model}

The updated transient-state model of the ground-water system in northern Utah Valley can be improved by making revisions on the basis of currently available data and information. The addition of many wells completed at different depths in the study area provides water levels in areas where information was not available prior to 1981. Revised water levels for the model representing steady-state conditions would reduce the offset between measured and computed water levels. Transient-state calibration to water levels measured during periods of climatic extremes, such as during the 1980s and early 2000s, and to increased withdrawals in some areas, would increase the range in which the model was tested. 


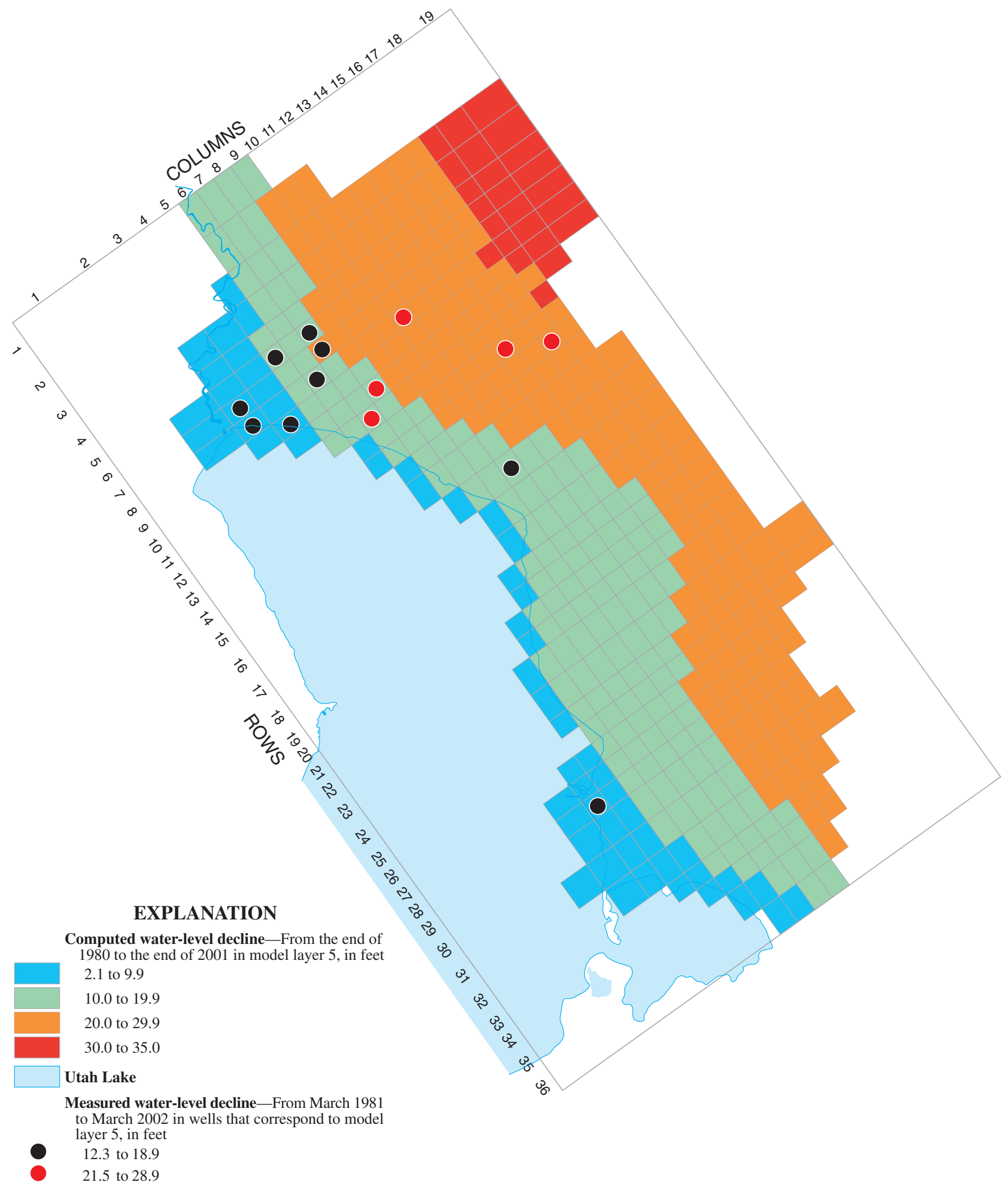

Figure 10. Computed water-level decline from the end of 1980 to the end of 2001 in layer 5 of the updated model of the ground-water system and measured water-level decline from March 1981 to March 2002 at 14 wells that correspond to layer 5 in northern Utah Valley, Utah. 

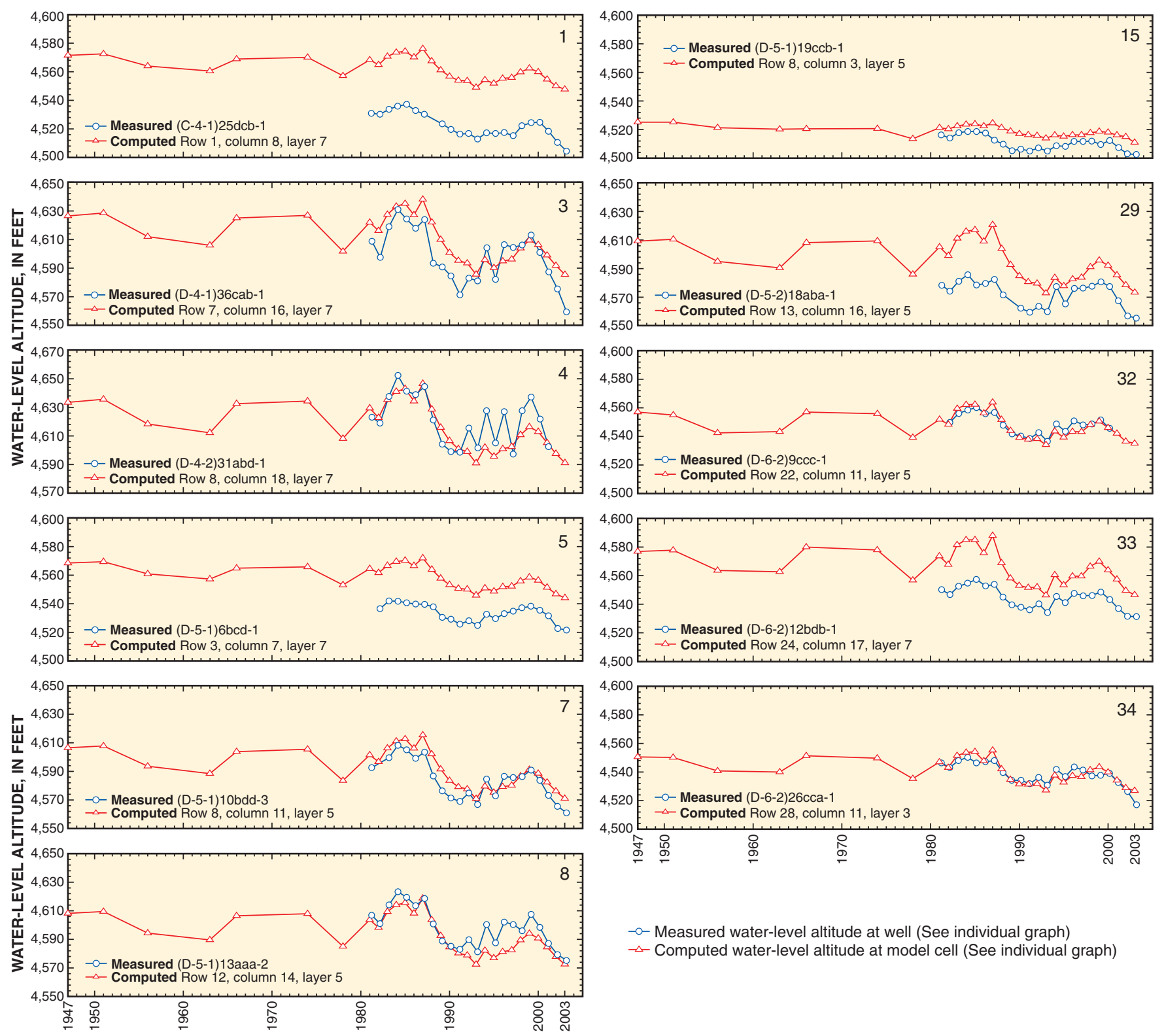

$-\infty$ Measured water-level altitude at well (See individual graph)

$\triangle-$ Computed water-level altitude at model cell (See individual graph)

Figure 11. Measured water-level altitude for selected wells during 1981-2003 and computed water-level altitude for the corresponding cell and layer in the updated model of the ground-water system in northern Utah Valley, Utah.

A refinement to the model that could improve its representation of the conceptual ground-water system is to vary discharge from flowing wells on the basis of land use and water-level changes over time. Discharge from flowing wells likely has decreased since 1980 because of changes in land use from agricultural to residential and a corresponding decrease in water use from flowing irrigation wells. Many flowing wells used for irrigation are no longer used or have been abandoned because of an ongoing decrease in agricultural acreage. Discharge from flowing wells also is affected by the water level in the aquifer: increased withdrawals from pumping wells have lowered the artesian pressure resulting in the potentiometric surface dropping below land surface during the irrigation season in some areas. Water-level rises caused by greater-than- average recharge would increase discharge from flowing wells in some areas. Simulating fluctuation in the discharge from flowing wells on the basis of the amount of irrigated land and on water levels could provide a more reasonable estimate of discharge than the original method of increasing flowing-well discharge proportionally with withdrawals from pumping wells to satisfy demands for irrigation.

The ground-water flow model of northern Utah Valley could be improved by updating it to operate with newer simulation methods, such as MODFLOW-2000 (Harbaugh and others, 2000; Hill and others, 2000). The parameter estimation package of MODFLOW-2000 uses a more efficient and objective method of calibration and provides a quantitative assessment of model uncertainty. 


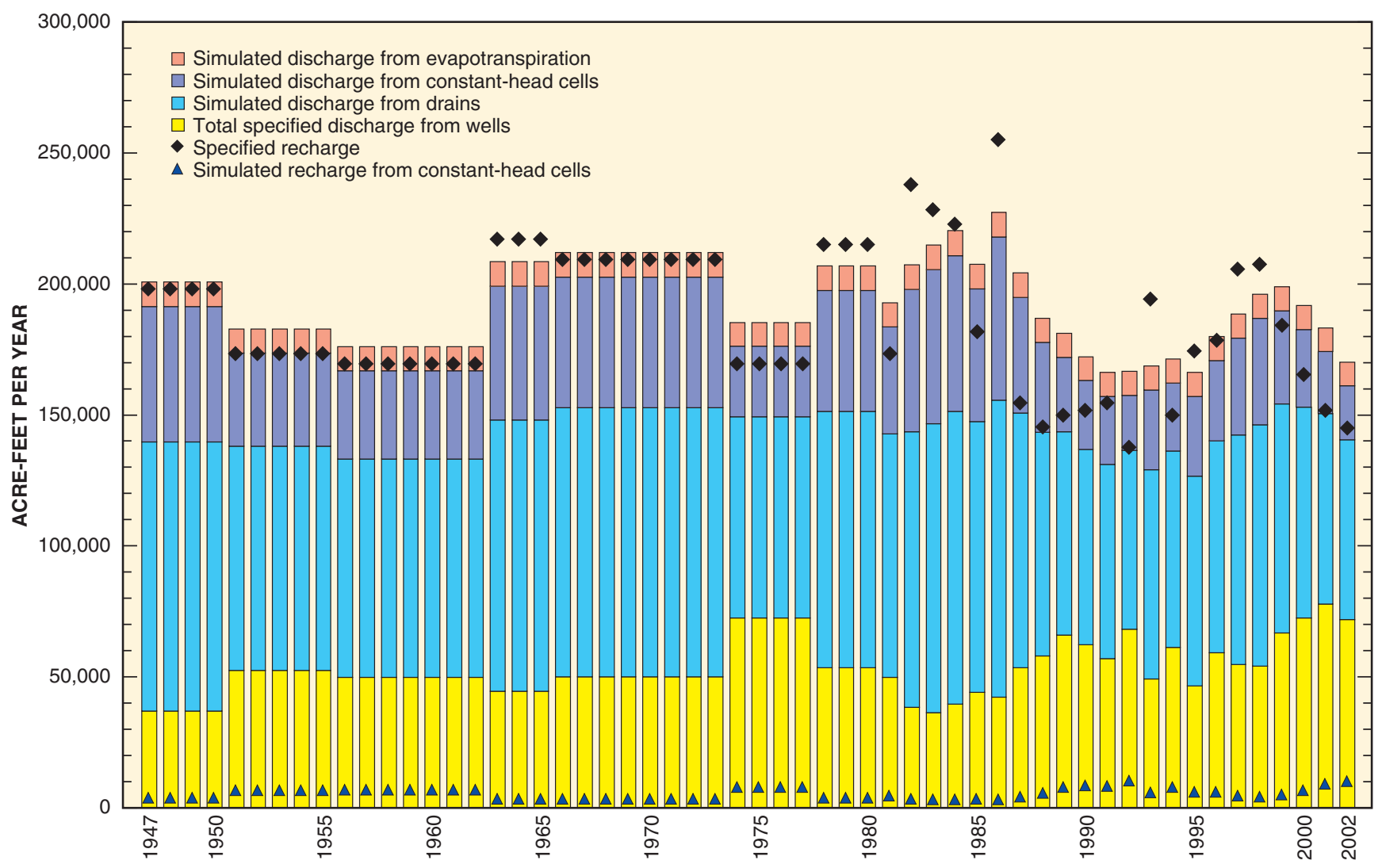

Figure 12. Simulated and specified ground-water recharge and discharge in the updated model of the ground-water system in northern Utah Valley, Utah, 1947-2002.

Ground-water discharge data in addition to water-level data are important to constrain ground-water flow models. Information on discharge from springs, seeps, and drains near Utah Lake measured during the modeled transient period and incorporated into the calibration process, would further constrain the model.

More wells have been completed in the aquifer contained within the Quaternary/Tertiary-age sediments (model layer 7 ) in the modeled area since the completion of the original ground-water flow model. Information about aquifer properties such as hydraulic conductivity, transmissivity, and storage coefficient estimated from these wells and used to simulate layer 7 could improve the model.

Environmental-tracer data, such as tritium, helium-3, and helium-4 concentrations, collected as part of the larger study, are being used to estimate residence time in the ground-water system along selected flow paths. The simulated time of travel to a cell and layer can be compared to estimates of groundwater ages for selected locations and aquifers in the calibration process using MODPATH (Pollock, 1994). MODPATH is a particle-tracking postprocessing package that was developed to compute three-dimensional flow paths using output from steady-state or transient ground-water flow simulations by MODFLOW.
The original ground-water flow model did not include the basin-fill deposits west of the Jordan River and Utah Lake. Ground-water development is occurring in that area, including production wells completed in the consolidated rock west of and underneath the basin-fill deposits, outside of the extent of active cells in the original model. These wells, along with recent geologic mapping of the area, can provide more information on the extent and thickness of the model layers west of the Jordan River and Utah Lake. The extent of the original model grid would have to be expanded to include this information.

The current study (2003-06) of the ground-water system in northern Utah Valley is developing a new, aerially expanded ground-water flow model for the area that incorporates these suggestions and data. This new model will serve as a tool to help understand the effects of increased development and changing water use on the ground-water resources. 


\section{Summary}

The U.S. Geological Survey began a 4-year study of the ground-water system in northern Utah Valley, Utah, in 2003 in cooperation with the Central Utah Water Conservancy District; Jordan Valley Water Conservancy District representing Draper City; Highland Water Company; Utah Department of Natural Resources, Division of Water Rights; and the municipalities of Alpine, American Fork, Cedar Hills, Eagle Mountain, Highland, Lehi, Lindon, Orem, Pleasant Grove, Provo, Saratoga Springs, and Vineyard. This report is one component of the study that evaluates the performance of a numerical model of the ground-water system in northern Utah Valley that originally simulated ground-water conditions during 1947-1980 and was updated to include conditions estimated for 19812002. Estimates of annual recharge to the ground-water system and discharge from wells in the area for 1981-2002 were added to the original ground-water flow model of the area.

The files used in the original transient-state model of the ground-water flow system in northern Utah Valley were imported into MODFLOW-96, an updated version of MODFLOW. The main model input files modified as part of this effort were the well and recharge files. Other parts of the updated model are the same as in the original model, except for factors related to the extended simulation period. Discharge from pumping wells in northern Utah Valley was estimated on an annual basis for 1981-2002. Although the amount of average annual withdrawals from wells has not changed much since the previous study, there have been changes in the distribution of well discharge in the area. Discharge estimates for flowing wells during 1981-2002 were assumed to be the same as those used in the last stress period of the original model because of a lack of new data.

Variations in annual recharge were assumed to be proportional to changes in total surface-water inflow to northern Utah Valley. The initial rate of recharge obtained from the steady-state calibration was 190,000 acre-ft/yr. This was multiplied by one-half of the percentage change from the average surface-water inflow during a given time period and applied to all of the model cells simulating recharge. Recharge to the ground-water system may change substantially from one year to the next, and such changes are a major cause for variations of water levels in northern Utah Valley. Recharge specified in the model during the additional stress periods varied from 255,000 acre-ft in 1986 to 137,000 acre-ft in 1992.

The ability of the updated transient-state model to match hydrologic conditions estimated for 1981-2002 was evaluated by comparing water-level changes measured in wells to those computed by the model. Water-level measurements made in February, March, or April were available for 39 wells in the modeled area during all or part of 1981-2003. Most of the water-level measurements were made during the month of March, a time of the year when there is less stress on the ground-water system from pumping, evapotranspiration, snowmelt runoff, or irrigation. This water-level measurement was used to represent the cumulative effects from the preceding year on ground-water conditions at each well.

In most cases, the magnitude and direction of annual water-level change from 1981 to 2002 simulated by the updated model reasonably matched the measured change. The greater-than-normal precipitation that occurred during 1982 84 resulted in period-of-record high water levels measured in many of the observation wells in March 1984. The modelcomputed water levels at the end of 1982-84 also are among the highest for the period. Both measured and computed water levels decreased during the period representing ground-water conditions from 1999 to 2002. Precipitation was less than normal during 1999-2002.

The ability of the model to adequately simulate climatic extremes such as the wetter-than-normal conditions of 1982-84 and the drier-than-normal conditions of 1999-2002 indicates that the annual variation of recharge to the groundwater system based on streamflow entering the valley, which in turn is primarily dependent upon precipitation, is appropriate but can be improved. The updated transient-state model of the ground-water system in northern Utah Valley can be improved by making revisions on the basis of currently available data and information.

\section{References Cited}

Burden, C.B., and others, 2004, Ground-water conditions in Utah, spring of 2004: Utah Department of Natural Resources Cooperative Investigations Report No. 45, 120 p.

Clark, D.W., 1984, The ground-water system and simulated effects of ground-water withdrawals in northern Utah Valley, Utah: U.S. Geological Survey Water-Resources Investigations Report 85-4007, 56 p.

Clark, D.W., and Appel, C.L., 1985, Ground-water resources of northern Utah Valley, Utah: Utah Department of Natural Resources Technical Publication No. 80, 115 p.

Harbaugh, A.W., Banta, E.R., Hill, M.C., and McDonald, M.G., 2000, MODFLOW-2000, the U.S. Geological Survey modular ground-water model-User guide to modularization concepts and the ground-water flow process: U.S. Geological Survey Open-File Report 00-92, 121 p.

Harbaugh, A.W., and McDonald, M.G., 1996, User's documentation for MODFLOW-96, an update to the U.S. Geological Survey modular finite difference ground-water flow model: U.S. Geological Survey Open-File Report 96-485, $56 \mathrm{p}$. 
Hill, M.C., Banta, E.R., Harbaugh, A.W., and Anderman, E.R., 2000, MODFLOW-2000, the U.S. Geological Survey modular ground-water model-User guide to the observation, sensitivity, and parameter-estimation process and three post-processing programs: U.S. Geological Survey OpenFile Report 00-184, 209 p.

Konikow, L.F., and Bredehoeft, J.D., 1992, Ground-water models cannot be validated: Advances in Water Resources, v. 15 , no. 1 , p. $75-83$.

McDonald, M.G., and Harbaugh, A.W., 1988, A modular three-dimensional finite-difference ground-water flow model: U.S. Geological Survey Techniques of WaterResources Investigations, book 6, ch. A1, 586 p.

Pollock, D.W., 1994, User's guide for MODPATH/MODPATH-PLOT, Version 3: A particle tracking post-processing package for MODFLOW, the U.S. Geological Survey finite-difference ground-water flow model: U.S. Geological Survey Open-File Report 94-464. 


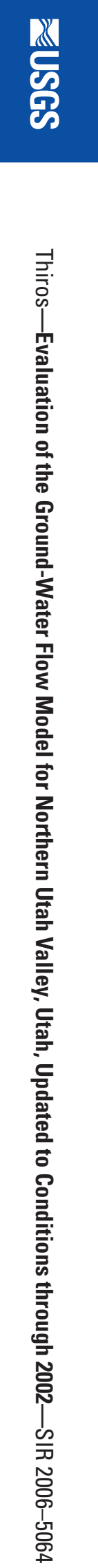